\title{
CONCENTRATION OF MEGALOBLASTS
}

\section{AN AID IN THE DIAGNOSIS OF PERNICIOUS ANAEMIA}

\author{
BY
}

\author{
K. S. RODAN \\ From Southlands Hospital, Shoreham-by-Sea
}

(RECEIVED FOR PUBlication, MARCH 31, 1949)

Typical megaloblasts, whose presence is so essential for the diagnosis of pernicious anaemia, are not often seen in the peripheral blood film. A method of concentrating these cells, therefore, should be of great assistance in the diagnosis.

The buffy coat in a haematocrit tube consists of white cells, which, in spite of their larger size, fall with less velocity than the smaller red cells. This consideration suggested that the bigger, nucleated red cells might be found in increased numbers in or immediately beneath the white cell layer, and this has proved to be the case. Incidentally, both macrocytes and microcytes are found concentrated in this area, thus exaggerating the typical pernicious anaemia picture. A further point of interest is the study of the white cells themselves, which in ordinary films are very scarce, owing to the generally occurring leucopenia. Cooke's Type I and II cells can thus be conveniently studied.

\footnotetext{
Method

Venous blood is collected in a tube containing Wintrobe's oxalate mixture, centrifugalized in a haematocrit tube, and the mean cell volume reading taken in the usual way. A Pasteur pipette; with an even tip, is then carefully inserted and part of the white layer, as well as the corpuscles immediately below it, aspirated. Enough plasma is normally obtained by the capillary action of the pipette for the resuspension of the cells. A small drop is placed on one end of a clean slide, and with a corner of
}

another the cells are gently mixed and quickly spreag in the usual manner. Three to six slides are made, as it will be found that the staining capacity, as well as the concentration of nucleated cells, varies betwee films. Megaloblasts at different stages of maturit will sometimes be found in different films. The films are allowed to dry and stained at once. It will be found that, in general, cells: are well stained, little distorted, and easily recognizable. No rouleaux formation is seen. Sometimes, however, distortiog is such as to prevent accurate determination of thei贯 structure, and it is advisable in such cases to repeat centrifugalization at a lower speed and for a shorteo time.

In twelve cases examined, only one did not show typical megaloblasts in the peripheral film by the concentration method. Five minutes' search revealed on an average 12 nucleated erythrocytes. In contras? only two cases showed megaloblasts without concen? tration. When sternal punctures were performed to complete a full examination this step proved superflu ous in 11 cases. The daily use of the concentration method after the beginning of liver treatment showed that the megaloblasts survived for three or four days in the peripheral blood. Disappearance of these cells therefore, is an indication of response to liver treate ment. Although the method described gave goo results in pernicious anaemia, there is no advantage in its use in hypochromic anaemias. One case of aleukaemic leukaemia was examined, and it seemeAs to be of value in the diagnosis.

I wish to thank Dr. F. C. O. Valentine for hisi comments, and Miss D. Low and Mr. J. Newmanis technicians at South Shields, for their assistance. 